\title{
Multiple congenital pericardial cysts mimicking pleural effusion on diagnostic imaging
}

\author{
Ting Sun ${ }^{1 \#}$, Jie-Zhou Huang ${ }^{2 \#}$, Guo-Liang Lu ${ }^{2 \#}$, Shao-Bo Xie ${ }^{2 \wedge}$ \\ ${ }^{1}$ Department of Ultrasonography, ${ }^{2}$ Department of Cardiovascular Surgery, The First Affiliated Hospital of Guangzhou Medical University, \\ Guangzhou, China \\ \#These authors contributed equally to this work.
}

Correspondence to: Shao-Bo Xie. Department of Cardiovascular Surgery, The First Affiliated Hospital of Guangzhou Medical University, Guangzhou, China. Email: xieshaobo2015@163.com.

Submitted May 30, 2020. Accepted for publication Jun 24, 2020.

doi: 10.21037/qims-20-717

View this article at: http://dx.doi.org/10.21037/qims-20-717

A 3-year-old girl with a 1-month history of progressive dry cough and dyspnea presented to our center. She was $97 \mathrm{~cm}$ tall and weighed $13 \mathrm{~kg}$. Chest X-ray and computed tomography suggested massive pleural effusion. Transthoracic echocardiography revealed a large echofree space around the pericardium, which was visible only on the subcostal view. Percutaneous fine-needle aspiration yielded bloody fluid, and cytological examination indicated no inflammatory, hemorrhagic, or malignant cells. The patient was discharged with suspected tuberculosis, and oral isoniazid $0.1 \mathrm{~g}+$ pyrazinamide $0.375 \mathrm{~g}+$ rifampicin $0.15 \mathrm{~g}$ was prescribed.

On follow-up examination one month later, the patient's symptoms recurred. Repeated chest X-ray and computed tomography revealed abnormal soft tissue densities along the paracardiac silhouette on the left and right heart borders. Considering these findings, a clinical and radiological diagnosis of multiple pericardial cysts was made. Because of the rapid growth, we performed a median sternotomy and completely excised the cysts, which measured $3 \times 5 \mathrm{~cm}$ on the right and $5 \times 8 \mathrm{~cm}$ on the left. The cysts were adherent to the pericardial surface and included mesothelial cells and collagenous tissue, which was compatible with congenital benign pericardial cysts.

Pericardial cysts are usually congenital in origin, but other causes such as hydatid infection have been described (1). The cysts can be single, unilocular or multilocular (2), and are most frequently located in the right costophrenic angle (3). To the best of our knowledge, this is the first report of multiple congenital pericardial cysts mimicking pleural effusion. Diagnosing this disorder as the current case (Figure 1) by imaging can be challenging.

\section{Acknowledgments}

Funding: None.

${ }^{\wedge}$ Ting Sun, ORCID: 0000-0001-7004-6352; Shao-Bo Xie, ORCID: 0000-0003-3599-7413 

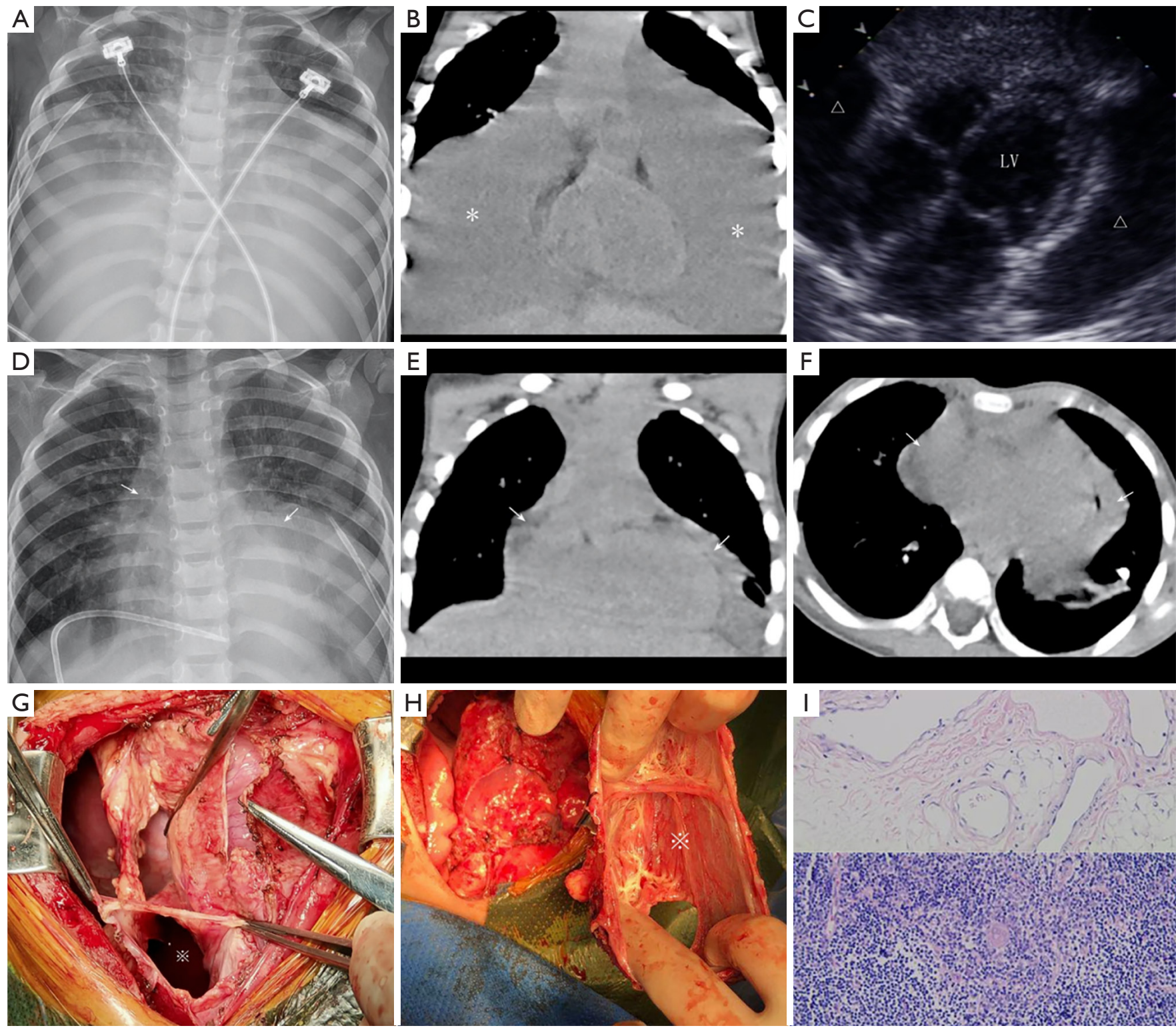

Figure 1 Multiple congenital pericardial cysts mimicking pleural effusion, Chest X-ray (A) and computed tomography (B) suggest massive pleural effusion $\left(^{*}\right)$. Transthoracic echocardiography $(\mathrm{C})$ revealed a large echo-free space $(\triangle)$ around the pericardium. Repeated chest X-ray $(\mathrm{D})$ and computed tomography (E,F) reveal abnormal soft tissue densities $(\rightarrow)$ along the paracardiac silhouette on the left and right heart borders. A median sternotomy and complete cysts excision $(※)$ were performed $(\mathrm{G}, \mathrm{H})$. The cysts included mesothelial cells and collagenous tissue (I).

\section{Footnote}

Conflicts of Interest: All authors have completed the ICMJE uniform disclosure form (available at http://dx.doi. org/10.21037/qims-20-717). The authors have no conflicts of interest to declare.

Ethical Statement: All procedures performed in studies involving human participants were in accordance with the Declaration of Helsinki (as revised in 2013). The authors confirm that written consent for submission and publication of this report including images and associated text has been obtained from guardian of the patient.

Open Access Statement: This is an Open Access article 
distributed in accordance with the Creative Commons Attribution-NonCommercial-NoDerivs 4.0 International License (CC BY-NC-ND 4.0), which permits the noncommercial replication and distribution of the article with the strict proviso that no changes or edits are made and the original work is properly cited (including links to both the formal publication through the relevant DOI and the license). See: https://creativecommons.org/licenses/by-ncnd/4.0/.

\section{References}

1. Balani A, Kumar AD, Dey AK. Intramyocardial hydatid

Cite this article as: Sun T, Huang JZ, Lu GL, Xie SB. Multiple congenital pericardial cysts mimicking pleural effusion on diagnostic imaging. Quant Imaging Med Surg 2020;10(9):18841886. doi: 10.21037/qims-20-717 cyst: a case report. Eur Heart J Case Rep 2018;2:yty053.

2. Maisch B, Seferović PM, Ristić AD, Erbel R, Rienmüller R, Adler Y, Tomkowski WZ, Thiene G, Yacoub MH, Task Force on the Diagnosis and Management of Pricardial Diseases of the European Society of Cardiology. Guidelines on the diagnosis and management of pericardial diseases executive summary; The Task force on the diagnosis and management of pericardial diseases of the European society of cardiology. Eur Heart J 2004;25:587-610.

3. Demos TC, Budorick NE, Posniak HV. Benign mediastinal cysts: pointed appearance on CT. J Comput Assist Tomogr 1989;13:132-3. 